British Journal of Education

Vol.8, Issue 1, pp.1-9, January 2020

Published by ECRTD- UK

Print ISSN: ISSN 2054-6351 (print), Online ISSN: ISSN 2054-636X (online)

\title{
EFFECT OF SOCIETAL PREJUDICE ON THE EDUCATIONAL ATTAINMENT OF PERSONS WITH DISABILITIES IN NIGERIA
}

\author{
Ihunwo, Patience \\ Department of Educational Foundations, Faculty of Education, University Of Port Harcourt,
} Nigeria

\begin{abstract}
The educational sector in Nigeria has attracted numerous debates among scholars particularly with regard to unequal opportunities for the citizenry. The persons with disabilities in the society have experienced the brunt of these unequal opportunities to education as they are little or no facilities available to aid their educational process. In addition, societal prejudices continues to deny them opportunities to attain heights of educations as families see them as burden and a waste of funds educating them. This is particularly worsened by religious and cultural inspired prejudices that tend to derogate persons with disabilities. This paper therefore seeks to investigate the impact of religious and cultural inspired prejudices on the educational attainment of persons with disabilities in Nigeria as well as the impact of societal prejudice on policy implementations that favour the education of persons with disabilities. To achieve these objectives, the study adopted the descriptive survey research approach and the target population for this study comprised of students, teachers, administrators within Oshimili South local government of Delta State. A sample of 26 administrators, 280 students and 228 teachers were selected and data collected using a structured questionnaire, while data was analyzed employing descriptive and content analysis. The relationship between variables was tested employing the chi-square test. The results from the research establish that education impacts national development in the country. In addition, the finding indicates that religious and cultural prejudices impacts the educational attainment of persons with disabilities in the society and this is worsened by the inadequate number of policies and infrastructures that aid in quality education for the persons with disabilities in the country.
\end{abstract}

KEYWORDS: education, persons, disabilities, prejudice

\section{INTRODUCTION}

No society can exist without education as it has been long established that education facilitates the advancement of societies. Scholars assert that education contributes to the innovations in technology, increase in the rate employment and income generation, and poverty reduction to mention but a few (Aghion et al, 2009; Omoniyi, 2013). Furthermore education equips the populace on necessary skills to be used within the society (Adetula et al 2017). It brings about all round development with regard to intellectual, spiritual, moral and physical advancements. In realization of the importance of education to societal development, the United National declared education as a fundament right of every individual (Maigida, Ibrahim, Agbonlahor, Afu et al., 2017). Nevertheless education of Nigerians has however faced a number of challenges and one section of this populace that has been immensely impacted are persons with disabilities. 
It is estimated that over 20 million people are living with disability in Nigeria (Haruna, 2017). This according to Akinkugbe et al (2010) can be linked to fatal road accidents, mental illness, paralysis, chronic diseases such as small pox, polio, melanoma, stroke, tuberculosis, cardiovascular diseases as well as meningitis.

\section{Concept of Persons with disabilities}

Persons with disabilities have been describes as persons with deficiencies that sees physical and societal barriers prevent them from activity participating in the normal activities of the society he finds himself (REF). Furthermore, a person with disability is any individual who is incapable of obtaining for himself completely or in parts normal requirements of a person and is incapable of participating completely in the society as a result of shortcoming either mentally or physically (Haruna, 2017). Adina (2011) postulates that a person may be classified as disabled if in the past he had a deficiency or is regarded as disabled on the basis of deficiencies that include sensory, physical or developmental impairments. According to Clapton \& Fitzgerald (2007) it is a medical situation caused by disease, shock or other health conditions that influences how an individual goes about his daily activities.

\section{Classification of Persons with Disabilities \\ - $\quad$ Sensory Disability \\ - $\quad$ Psychological and Emotional Disability \\ - $\quad$ Visual Disability \\ - $\quad$ Physical Disability \\ - $\quad$ Hearing and Gustatory Impairment \\ - Intellectual Disability}

\section{Societal Prejudice of Persons with disabilities}

The perception of societies towards persons with disabilities varies, in some cases they are viewed as an essential part of the society whilst in other circumstances they are neglected and isolated. This perception can be traced to the medieval eras where disabled persons were regarded as clowns for the amusement of their masters (Haruna, 2017). In the Nigerian context, mental retardation, blindness, physical impairments are isolated, marginalized and neglected by the society. This stems from religious and cultural beliefs surrounding the birth of persons with disability.as such, they are denied from playing any significant role in the society, stigmatized and intimidated by members of the society (Etieyibo \& Omiegbe, 2016). According to a report by Lawal (2013) women who are disabled by "Vesico Vaginal Fistula" are abandoned by their family members and the community. As such, societal prejudice can be defined as any form whether social, racial, religious motivation that brings about negative attitudes towards member of a particular social group (Omoniji \& Nnedum, 2012). Societal prejudice has seen worrying levels of hostility towards persons with disability by the society (Uzochukwu, Akpala \& Onwujekwe, 2004). According to Falobu \& Akanbi (2009) most of them find it difficult to gain employment, marry are snubbed and embarrassed in the public. Researchers establish that they are often seen in streets in the country begging for alms (Omoniji \& Nnedum, 2012). These conditions make them suicidal and regretful. 


\section{Societal Prejudices of Persons with disabilities in Education}

In recognition of the challenges faced by persons with disabilities numerous regulations and policies were enacted to improve the welfare and protect the rights of persons with disabilities such as "Rights of Persons with Disabilities Act", "Discrimination Against person with Disabilities Act of 2018" to mention a few. One of these policies is the resolution by UNESCO that education should be for all (Ebong \& Asodike, 2005). According to Abraham \& Leigha (2008) the implication is that education should be provided for every child living in the country regardless of health conditions, physical impairments, financial status and ethnicity. These policies have been put in place to support the education of persons with disabilities. However Eskay (2001) highlights that some administrators remain skeptical and opposed to the education of persons with disabilities as they believe it is a waste of resources. This clearly indicates that persons with disabilities have continued to experience discrimination in the Nigerian society over the years (Fatunde, 2009; Eskay et al., 2012; Etieyibo \& Omiegbe; 2016).

\section{Statement of the Problem}

Scholars have long perceived disability as the inability to effectively carry out activities in the manner considered normal for an individual. According to Clapton \& Fitzgerald (2007) it is a medical situation initiated by disease, shock or other health circumstances which influences how an individual goes about his daily activities. However, Omoniji \& Nnedum (2012) opine that there are individuals with physical challenges capable of contributing enormously to the national growth of the nation and these negative description or ascription of persons with disabilities has seen millions of challenged individuals experience prejudice in their homes, work place, hospitals and the society in general rather than encourage and alleviate their sufferings.

The society should be held accountable for the negative attributions placed on persons with disabilities. According to Thomas \& Thomas (1999) societal practices such as taboo and superstitions as well as expectations influence how individuals view disability and this has gone a long way in impacting the educational attainment of persons with disabilities in Nigeria. According to Adebisi, Jerry, Rasaki \& Igwe (2014) these negative societal perception towards persons with disability has seen facilities that aids these persons with special needs are unavailable or outdated. According to Kabuta (2014) many students who enroll into tertiary institutions are left frustrated because of the non-existence of support services for them. Nkechi (2013) postulates that the policies aimed at developing inclusive education have failed to be implemented thus inhibiting access to education for individuals with special needs. This can be attributed to the societal prejudices attached to caring for the persons with disabilities in Nigeria.

\section{Objectives of the Study}

- $\quad$ To investigate the impact of prejudices on the implementation of policies that protect and improve the welfare of persons with disabilities.

- To investigate the relationship between religious perceptions towards the educational attainment of persons with disabilities.

- To investigate the relationship between cultural perceptions towards the educational attainment of persons with disabilities. 
British Journal of Education

Vol.8, Issue 1, pp.1-9, January 2020

Published by ECRTD- UK

Print ISSN: ISSN 2054-6351 (print), Online ISSN: ISSN 2054-636X (online)

\section{Research Hypotheses}

Ho: There is no significant relationship between prejudices and the implementation of policies that protect and improve the welfare of persons with disabilities.

Ho: There is no significant relationship between religious perceptions and the educational attainment of persons with disabilities.

Ho: There is no significant relationship between cultural perceptions and the educational attainment of persons with disabilities.

\section{RESEARCH METHODOLOGY}

The research design adopted for the study is the descriptive survey approach. According to Orodho \& Kombo (2002) it a form of research approach that is employed when information regarding the welfare of an individual or object is sort. This approach is appropriate for this research in the sense that it is effective in gathering data across a large number of participants from the sampled local government.

i. Study Population

The population targeted for the research comprised of students, teachers, administrators within Oshimili South local government of Delta State.

ii. Sampling Procedure

For the purpose of the research the sample was selected employing random sampling approach in the sense that the sample size was in randomly selected from the population.

iii. Sample Size

Upon employing the random selection approach the sample size obtained for the study was 554 respondents made up of 26 administrators, 280 students and 228 teachers.

iv. Data Collection

The data collected for the research was obtained using a semi-structured questionnaire and the items on the questionnaire were based on the objectives of the study which were to determine the relationship between; societal prejudices and policy implementation, religious perception and education attainment as well as cultural perception and educational attainment of persons with disabilities respectively. The questionnaire had open and closed items accompanied by a number of possible alternatives that allowed the participants selected answers they felt suited their perceptions.

v. Data Analysis

Both Qualitative and Quantitative techniques were employed to analyse data while the Chi-Square test was employed to establish the relationship between the independent and dependent variables. In addition, 448 respondents actually completed their questionnaire. 
Vol.8, Issue 1, pp.1-9, January 2020

Published by ECRTD- UK

Print ISSN: ISSN 2054-6351 (print), Online ISSN: ISSN 2054-636X (online)

\section{RESULT PRESENTATION AND DISCUSSION}

Table 1.1 Societal prejudice impact policy implementations for persons with disabilities

\begin{tabular}{|l|l|l|}
\hline Response & Frequency & $\%$ \\
\hline Yes & 156 & 68.4 \\
\hline No & 72 & $\mathbf{3 1 . 6}$ \\
\hline Total & 228 & $\mathbf{1 0 0 . 0}$ \\
\hline
\end{tabular}

As shown in Table 1.1, 68.4 percent of the respondents perceived that societal prejudice influenced policy implementations that favored and aided persons with disabilities. While 31.6 percent perceived that societal prejudice did not influence policy implementations that favored and aided persons with disabilities. In essence, the findings established that the welfare and rights of persons with disabilities were been stalled as a results of societal prejudice by policy makers and the society in general. These viewpoints are in agreement with the propositions by Akogun, Njobdi \& Adebukola (2018) that even though Nigeria is a signatory to numerous international declarations such as the Salamanca Declaration of 1994, Standard Rules on the Equalization of Opportunities for persons with disabilities UNCRPD of 2006 which all recognize the rights of quality and inclusive education for persons with disabilities, most of the policies have not been fully implemented.

Table 1.2 Chi-square test on societal prejudice and policy implementation for persons with disabilities.

\begin{tabular}{|l|l|l|l|}
\hline & Value & Df & $\begin{array}{l}\text { Asymp. Sig. (2- } \\
\text { sided) }\end{array}$ \\
\hline Pearson Chi-Square & $198.509^{\mathrm{a}}$ & 3 & .000 \\
\hline Likelihood Ratio & 186.683 & 3 & .000 \\
\hline $\begin{array}{l}\text { Linear-by-Linear } \\
\text { Association }\end{array}$ & 129.842 & 1 & .000 \\
\hline N of Valid Cases & 228 & & \\
\hline
\end{tabular}

From table 1.5 above, it can be established that the Chi-square value is 198.509 while the p-value is obtained as 0.000 lower than 0.05 showing that cultural perceptions significantly influence the educational attainment of persons with disabilities. Therefore on the basis of this discovery, the hypothesis was rejected. 
Impact of religious perceptions on educational attainment of persons with disabilities

\section{Influence of Religious perceptions towards persons with disabilities on educational attainment}

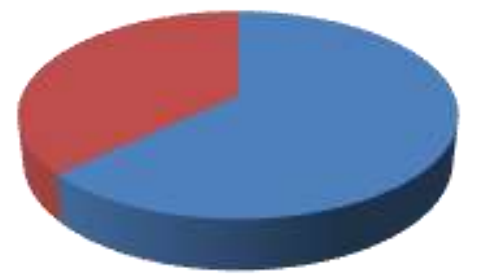

From the "results obtained from the data analysis it can be deduced that a significant (63\%) of the participants of the survey perceived that religious perceptions towards persons with disabilities impacted their educational attainment. This indicates that majority of the respondents opined that religious prejudice within the society impacted the educational attainment of persons with disabilities". This findings is in agreement with the proposition of numerous scholars, for instance, Ndlovu (2016) argues that African religious beliefs regarding persons with disabilities can pass them as forces of evil thereby stigmatizing and relegating them and withholding them the same rights as persons without disabilities. In addition, Okafor (2003) identifies that persons with disabilities are seen as cursed in essence serving punishment for the crimes caused by their generations and are therefore require no form of educational acquisition as they are hopeless.

Table 1.3 Chi-square test on religious perception and educational attainment for persons with disabilities.

\begin{tabular}{|l|l|l|l|}
\hline & Value & df & Asymp. Sig. (2-sided) \\
\hline Pearson Chi-Square & $129.975^{\mathrm{a}}$ & 4 & .000 \\
\hline Likelihood Ratio & 145.091 & 4 & .000 \\
\hline Linear-by-Linear Association & 106.746 & 1 & .000 \\
\hline N of Valid Cases & 228 & & \\
\hline
\end{tabular}

According to Table 1.3, the Chi-square value is 129.975 while the p-value is 0.000 which is less than 0.05 . These results therefore indicate that religious perceptions significantly influence the educational attainment of persons with disabilities in Nigeria. The hypothesis is therefore rejected. 
British Journal of Education

Vol.8, Issue 1, pp.1-9, January 2020

Published by ECRTD- UK

Print ISSN: ISSN 2054-6351 (print), Online ISSN: ISSN 2054-636X (online)

Impact of cultural perception on the educational attainment of persons with disabilities

Table 1.4 Cultural perceptions impacts educational attainment of persons with disabilities

\begin{tabular}{|l|l|l|}
\hline Response & Frequency & $\%$ \\
\hline Yes & 149 & 65.4 \\
\hline No & 79 & 34.6 \\
\hline Total & 228 & 100.0 \\
\hline
\end{tabular}

Based on the table above (Table 1.4) a significant number of the respondents representing 65.4 percent of the participants of the survey perceived that cultural beliefs influenced the educational attainment of persons with disabilities. This finding by the research is in agreement with the proposition of Etieyibo \& Omiegbe (2016) who argue that discriminatory actions carried out on persons are reinforced by cultural practices and beliefs, for instance, the Almajiri system that sustains the culture of using children with disabilities to beg for alms.

Table 1.5 Chi-square test on cultural perception and educational attainment for persons with disabilities

\begin{tabular}{|l|l|l|l|}
\hline & Value & df & $\begin{array}{l}\text { Asymp. Sig. (2- } \\
\text { sided) }\end{array}$ \\
\hline Pearson Chi-Square & $11.740^{\mathrm{a}}$ & 1 & .000 \\
\hline Continuity Correction & 108.569 & 1 & .000 \\
\hline Likelihood Ratio & 114.525 & 1 & .000 \\
\hline $\begin{array}{l}\text { Linear-by-Linear } \\
\text { Association }\end{array}$ & 111.249 & 1 & .000 \\
\hline N of Valid Cases & 228 & & \\
\hline
\end{tabular}

From the table 1.2 above it can be deduced, that the p-value is recorded as 0.000 and is lower than 0.005 while the Chi-square value is 111.740 . These results therefore establish that societal prejudice has a significant impact on policy implementation for persons with disabilities. Thus, the hypothesis is rejected.

\section{CONCLUSION}

This paper sort to investigate societal prejudice towards the educational attainment of persons with disabilities. It establishes the impact of education of national development and highlights the level of illiteracy in the country, religious fanatics and cultural fundamentalism and its impact on the education of persons with disabilities. This is worsened by the inadequate number of policies and infrastructures that aid in quality education for persons with disabilities in the country. As such, it identifies that societal prejudice significantly impacts the educational attainment of persons with disabilities in Nigeria. The paper therefore makes a number of recommendations which include;

- Implementation of policies that protect the rights of persons with disabilities

- $\quad$ Construction of facilities that support the education and welfare of persons with disabilities 
- $\quad$ Sensitization campaigns should be carried out across the country to enlighten the populace on the need to protect and educate persons with disabilities.

- $\quad$ Counseling centers should be established to help persons with disabilities cope with the trauma associated with its experience.

- Educational centers should introduce policies and infrastructures that enable the smooth transition of persons with disabilities from primary to secondary and finally tertiary institutions.

\section{REFERENCES}

Abraham, .M. \& Leigha, .B. (2008) Teaching Manpower and Infrastructure Availability in Migrant Fisherfolk Schools in Bayelsa: Implication for Access to Quality Basic Education.

Adebisi, R. O., Jerry, J. E., Rasaki, S. A., \& Igwe, E. N. (2014). Barriers to special needs education in Nigeria. International Journal of Education and Research, 2(11), 451-462.

Adetula, D. T., Adesina, K., Owolabi, F. O. L. A. S. H. A. D. E., \& Ojeka, S. (2017). Investment in Education for the Nigerian Economic Development. Journal of Internet Banking and Commerce.

Aghion, P., Boustan, L., Hoxby, C., \& Vandenbussche, J. (2009). The causal impact of education on economic growth: evidence from US. Brookings papers on economic activity, 1, 1-73.

Ajuwon, P. M. (2008). Inclusive Education for Students with Disabilities in Nigeria: Benefits, Challenges and Policy Implications. International journal of special education, 23(3), 1116.

Akinkugbe, O. O., Lucas, A. O., Onyemelukwe, O. C., Yahaya, H., \& Adamu, H. (2010). Noncommunicable diseases in Nigeria: The emerging epidemics. Health Reform Foundation of Nigeria (HERFON), 106.

Ebong, J. M., \& Asodike, J. D. (2005). Problems and challenges for quality delivery of preprimary (nursery) education in the Universal Basic Education (UBE) programme in Rivers State. African Journal of Education and Developmental Studies (AJEDS), 1, 116-122.

Etieyibo, E., \& Omiegbe, O. (2016). Religion, culture, and discrimination against persons with disabilities in Nigeria. African journal of disability, 5(1).

Fatunde, T., 2009, 'Disabled protest at discrimination', University world news, 15 November, $\begin{array}{llll}\text { viewed } & \text { October } & 2019, & \text { from }\end{array}$ [http://www.universityworldnews.com/article.php?story=20091113141506713]

Haruna, M. A. (2017). The problems of living with disability in Nigeria. JL Pol'y \& Globalization, 65, 103.1

Lawal, B. (2013). Psychosocial Health Consequences on Vesico Vaginal Fistula patients. Bayero Sociologist: A Journa of Sociological studies, 1(0), 4.

Omoniyi, M. B. I. (2013). The role of education in poverty alleviation and economic development: A theoretical perspective and counselling implications. British Journal of Arts and Social Sciences, 15(2), 176-185.

Omonijo, D. O. (2012). Impacts of Societal Prejudice on Attainment of Life/Personal Goals of Physically Challenged Persons in Nigeria. International Research Journal of Humanities, 4(5), 1-14. 
Okafor, L. (2003). Enhancing Business-Community Relations: Sir David Osunde Foundation Case Study. Sir David Osunde Foundation, 5.

Thomas, M., \& Thomas, M. J. (1999). Influence of cultural factors on disability and rehabilitation in developing countries. Asia Pacific Disability Rehabilitation Journal, 10(2), 44-46.

Kabuta, L. G. (2014). Problems facing students with physical disabilities in higher learning institutions in Tanzania (Doctoral dissertation, The Open University of Tanzania).

Ndlovu, H. L. (2016). African beliefs concerning people with disabilities: implications for theological education. Journal of Disability \& Religion, 20(1-2), 29-39.

Akogun, O., Njobdi, S., \& Adebukola, A., (2018) A Study of the Management and Implementation of the Policy on Special Education Needs and Disability for Improving Access Of Persons with Disabilities to Nigeria's Basic Education. Retrieved online from [http://www.nigeriaeducation.org/edoren/wp-content/uploads/2018/08/EDOREN-SEND-Final-report.pdf]

Cohrs, J. C., \& Duckitt, J. (2011). Prejudice, types and origins of. The Encyclopedia of Peace Psychology.

Hussain, I., \& Bashir, M. (2011). Problems Faced by Physical Handicapped Students in Educational Institutions in District Kohat. Contemporary Issues in Education Research, $4(2), 23-26$.

Eskay, M. (2001). Cultural perceptions of special education administrators in Nigeria. (Unpublished Doctoral Dissertation, Loyola University of Chicago, Chicago, IL.)

Eskay, M., Eskay, O., \& Uma, E. (2012). Educating People With Special Needs in Nigeria: Present and Future Perspectives. Online Submission.

Falobi B. and Akanbi, A. (2009)Nigeria: Celebrating Week of the Disabled. All African.com August 29th

Maigida, A., Ibrahim, O., \& Agbonlahor, A. (2017) Education of the Physically Handicapped: Within or Outside Context? Retrieved online on the $22^{\text {nd }}$ of October, 2017 from [file:///c:/users/user/desktop/disability/education_of_the_physically_handicapped.pdf]

Nkechi, C. M. (2013). Education of the disabled in Nigeria: Access and perception. Educația Plus, 9(1), 133-142.

Orodho, A .J. (2005).Elements of Educational and social sciences Research Methods. Nairobi: Masola Publishers.

Uzochukwu, B. S., Akpala, C. O., \& Onwujekwe, O. E. (2004). How do health workers and community members perceive and practice community participation in the Bamako Initiative programme in Nigeria? A case study of Oji River local government area. Social Science \& Medicine, 59(1), 157-162. 